\title{
HPTLC ANALYSIS OF Curcuma mangga Val. EXTRACTS AND THEIR IMMUNOMODULATORY EFFECTS ON DELAYED- TYPE HYPERSENSITIVITY RESPONSE
}

\author{
Yuandani $^{1, \bowtie}$, Sony Eka Nugraha ${ }^{2}$, Lia Laila ${ }^{3}$, Denny Satria ${ }^{2}$ and Rony Abdi \\ Syahputra ${ }^{1}$ \\ ${ }^{1}$ Department of Pharmacology, Faculty of Pharmacy/Universitas Sumatera Utara, Medan-20155, \\ Indonesia \\ ${ }^{2}$ Department of Pharmaceutical Biology, Faculty of Pharmacy/Universitas Sumatera Utara, \\ Medan-20155, Indonesia \\ ${ }^{3}$ Department of Pharmaceutical Technology, Faculty of Pharmacy/ Universitas Sumatera Utara, \\ Medan-20155, Indonesia \\ ${ }^{\boxplus}$ Corresponding Author: yuandani@usu.ac.id
}

\begin{abstract}
The purpose of the study was to analyze several extracts of Curcuma mangga rhizomes by HPTLC and determine their immunomodulatory effects on the Delayed-Type Hypersensitivity (DTH) response in Wistar rats. The C. mangga rhizomes were macerated with $73 ; 83$ and $99 \%$ ethanol separately. HPTLC analysis was performed to evaluate the content of curcumin in various extracts of $C$. mangga. The immunomodulatory potential on DTH response was investigated by measuring the paw volume. All extracts were tested at the dose of $400 \mathrm{mg} / \mathrm{kg}$ bw. Quantitative analysis using HPTLC revealed that among the samples tested, 99\% ethanol extract of $C$. mangga contained the highest amount of curcumin $(9.94 \mu \mathrm{g} / \mathrm{mL})$. All the samples tested stimulated DTH response. Amongst the extracts, $99 \%$ ethanol extract of $C$. mangga rhizomes demonstrated the highest stimulation on DTH response but it was not different significantly $(\mathrm{P}>0.05)$. However, the stimulatory activity of $99 \%$ ethanol extract of $C$. mangga was higher than levamisole as a positive control $(\mathrm{P}<0.05)$. The results indicate the presence of curcumin in $C$. mangga extract may contribute to its immunostimulatory activity.

Keywords: Curcuma mangga, Immunostimulatory, Delayed-Type Hypersensitivity (DTH) response, Ethanol Extract. RASĀYAN J. Chem., Vol. 14, No.3, 2021
\end{abstract}

\section{INTRODUCTION}

The immune response system should be modulated to manage and treat a variety of disorders, including inflammation, immunodeficiency, and infectious infections. ${ }^{1}$ Substances that are used to increase or decrease the immune system are called Immunomodulators. ${ }^{2}$ There are a variety of chemical immunomodulators on the market. Unfortunately, some of these over-the-counter medications have negative side effects. ${ }^{3}$ Natural products remain one of the valuable sources of innovative and safe immunomodulatory compounds. ${ }^{4}$ Ethnopharmacological data can be used to give preliminary data in the search for novel pharmaceuticals to discover safer drugs. ${ }^{5}$ The active compounds such as terpenoids, phenolics, and alkaloids are present in medicinal plants. ${ }^{6}$ Some medicinal plants have been proposed to have effects on immune response. ${ }^{7}$ Medicinal plants have been the subject of several ethnobotanical and phytochemical studies. Previous studies have indicated that plants in Genus Curcuma such as Curcuma mangga, Curcuma longa, Curcuma aeruginosa and Curcuma xanthorrhiza are able to modulate certain lineages of the immune response, thus they can be used to treat various diseases related to immune response. ${ }^{8-11}$

Curcumin is one major component present in Curcuma species. Our previous study reported that C. mangga rhizome contains curcuminoid (curcumin, desmethoxycurcumin and bidesmethoxycurcumin. ${ }^{12}$ Curcumin has a diverse set of biological properties, including anti-inflammatory and antibacterial properties. ${ }^{13}$ However, the investigation on curcumin content in C. mangga after extraction using various grades of ethanol as well as curcumin concentration and immunomodulatory action has rarely been linked in previous

Rasayan J. Chem., 14(3), 2085-2089(2021)

http://doi.org/10.31788/RJC.2021.1436247

This work is licensed under a CC BY 4.0 license. 
studies. The current study was conducted to perform High-Performance Thin Layer Chromatography (HPTLC) analysis to evaluate the amount of curcumin in C. mangga extracts obtained by maceration using different grades of ethanol as a solvent. Furthermore, the stimulatory effects on delayed-type hypersensitivity response of those extracts were investigated to correlate the activity with curcumin content.

\section{EXPERIMENTAL}

\section{Materials and Instruments}

The reagents used in this current study were natrium carboxylmethlcellulose (Na CMC) (Sigma, USA), ethanol (SmartLab, Indonesia). Mobile phase consists of benzene: chloroform ethanol absolute (Merck, Germany) was also used in this study. A rotary evaporator (Heidolph, Germany), Linomat 5 TLC spotter (Camag, Muttenz, Switzerland), glass chamber 20x20 cm, TLC scanner 3 (Camag, Muttenz, Switzerland), TLC documentation system (Camag, Muttenz, Switzerland) were also used in this study.

\section{Extraction Procedure}

The rhizomes were macerated using various grades of ethanol $(73 \%, 83 \%$ and $99 \%$ ethanol). The dried material (1500 g of C. mangga rhizomes) was separated into three parts and steeped in 73 percent ethanol for the first part, the second part was macerated with $83 \%$ ethanol, meanwhile, the last part was soaked with $99 \%$ ethanol. The extraction using each solvent was repeated two times. A rotary evaporator was used to remove the solvent, yielding different extracts of C. mangga rhizomes.

\section{Quantitative Analysis of Curcuma mangga extracts using High-Performance Thin Layer Chromatography (HPTLC)}

Curcumin was determined in three separate extracts ( 73 percent, 83 percent, and 99 percent ethanol extracts) using the High-Performance Thin Layer Chromatography technique. ${ }^{14}$ Briefly, $10 \mathrm{mg}$ curcumin (PT. FitoLab 99\%) was dissolved in a standard solution in $10 \mathrm{~mL}$ of methanol. Sample solutions were prepared by dissolving $100 \mathrm{mg} \mathrm{C}$. mangga extract $(73 \%, 83 \%$ and $99 \%)$ in $10 \mathrm{~mL}$ of ethanol absolute. Then, the samples were spotted $(10 \mu \mathrm{L})$ on a precoated silica gel glass plate $60 \mathrm{~F} 245(20 \mathrm{~cm}$ x $20 \mathrm{~cm})(\mathrm{E}$. Merck, Darmstad, Germany) with a micro liter syringe, the space between two spot was $10 \mathrm{~mm}$. The mobile phase was made up of benzene: chloroform : ethanol absolute (45:45:10). The length of neach run was $17 \mathrm{~cm}$ and performed in appropriate conditions with a temperature was $25 \pm 2^{\circ} \mathrm{C}$ and $\%$ Relative Humidity (\%RH) was $60 \pm 55$. After that, the plates were dried in the open air. A TLC scanner was used to do densitometric analysis at $425 \mathrm{~nm}$.

\section{Calibration Curve of Curcumin}

A standard compound stock solution $(1000 \mu \mathrm{g} / \mathrm{mL})$ was dissolved in methanol and spotted on TLC plate $10 ; 8 ; 6 ; 4 ; 2 \mu \mathrm{L}$, then a linear regression equation was used to analyze the data of peak area versus curcumin concentration. The levels of curcumin were determined by the substitution peak area of samples in the regression equation of standard (Curcumin).

\section{Antigen Preparation}

The antigen used was activated bacteria. Staphylococcus aureus was cultivated in nutrient broth agar (NBA) and incubated for $24 \mathrm{~h}$. Then, the cell concentration was adjusted to $1 \times 10^{8}$ cells $/ \mathrm{mL}$ using spectrophotometry. OD was measured in $580 \mathrm{~nm}$ with $20 \% \mathrm{~T}$. Thereafter, it was centrifuged (10.000 rpm; 10 minutes; $25^{\circ} \mathrm{C}$ ). The supernatant was discarded. Finally, the cells were resuspended with $1 \mathrm{~mL}$ of PBS.

\section{Delayed-Type Hypersensitivity (DTH) Response}

The response of DTH was evaluated by measuring paw volume according to a modified previous method. ${ }^{15}$ Animals were divided into 5 (five) groups for each condition, including:

1. $\mathrm{Na} \mathrm{CMC} 0.5 \%$ suspension

2. $73 \%$ ethanol extract of C. mangga $400 \mathrm{mg} / \mathrm{kg} \mathrm{BW}$

3. $83 \%$ ethanol extract of C. mangga $400 \mathrm{mg} / \mathrm{kg} \mathrm{BW}$

4. $99 \%$ ethanol extract of C. mangga $400 \mathrm{mg} / \mathrm{kg} \mathrm{BW}$

5. Levamisole $25 \mathrm{mg} / \mathrm{kg} \mathrm{BW}$ 


\section{RASĀYAN J. Chem.}

Vol. 14 | No. 3 |2085-2089| July - September | 2021

Animals were given a suspension of $C$. mangga extract in $\mathrm{Na} \mathrm{CMC}$ at a concentration of $0.5 \%, 72$ hours prior sensitization with $S$. aureus $\left(1 \times 10^{8}\right.$ cells $\left./ \mathrm{mL}\right)$ by intraperitoneal injection and continued until 14 days. Meanwhile, the group of negative control received vehicle only ( $\mathrm{Na} \mathrm{CMC} 0.5 \%$ ). As a positive control, levamisole $(25 \mathrm{mg} / \mathrm{kg} \mathrm{bw})$ was employed. On day 14 , the paw volume was measured, then, all the rats were challenged with $S$. aureus $\left(1 \times 10^{8}\right.$ cells $\left./ \mathrm{mL}\right)$ in the hind footpad. Then, after 24 hours the paw volume was measured again and the DTH response was determined. The procedure has been approved with approval number 0260/KEPH-FMIPA/20I9.

\section{Statistical Analysis}

The data were reported as the mean standard error of the mean (SEM). To determine the normality of the data, the Kolmogorov Smirnov and Shapiro Wilk tests were used. Then, Kruskal-Wallis and Mann-Whitney tests were performed to identify the difference.

\section{RESULTS AND DISCUSSION \\ Quantitative analysis of Curcuma mangga Extracts using HPTLC}

Our previous study demonstrated that C. mangga rhizomes contain curcuminoids. ${ }^{12}$ The purpose of this study was to determine the curcumin content in several extracts produced with various ethanol/water solvents. Curcumin was eluted with an Rf value of 0.69 , whereas $0.68,0.71$, and 0.68 were found in 73,83 and $99 \%$ ethanol extracts, respectively (Fig.-1). Calibration curves plotted were linear with a correlation coefficient $\left(r^{2}\right)$ of 0.9964 (Fig.- 2), indicating the linearity of the method used in this study. Table-1 shows that amongst the samples, $99.99 \%$ ethanol extract of $C$. mangga rhizomes was found to have the highest amount of curcumin $(9.94 \mu \mathrm{g} / \mathrm{mL})$. However, the $73 \%$ ethanol extract contained a higher amount of curcumin as compared to $83 \%$ ethanol extract of C. mangga rhizomes.

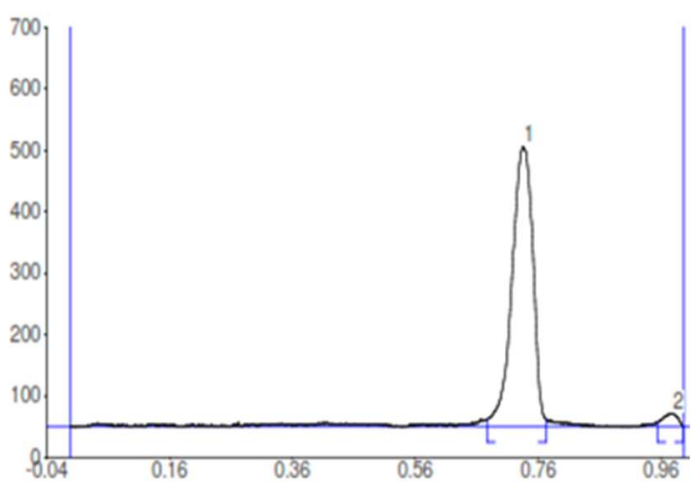

(a)

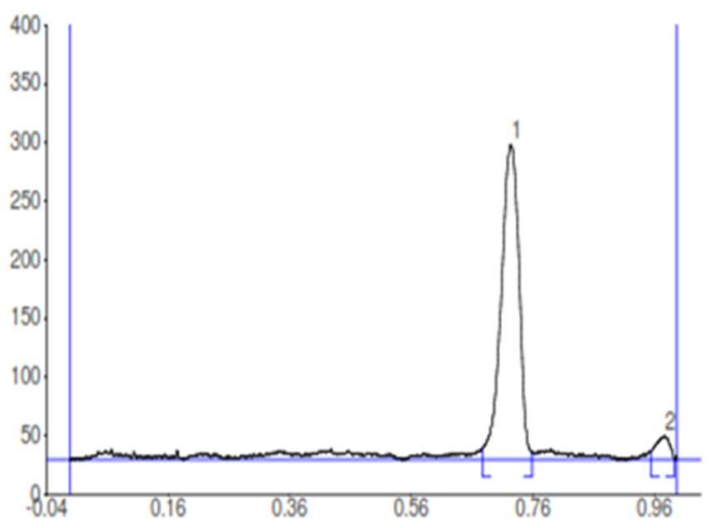

(c)

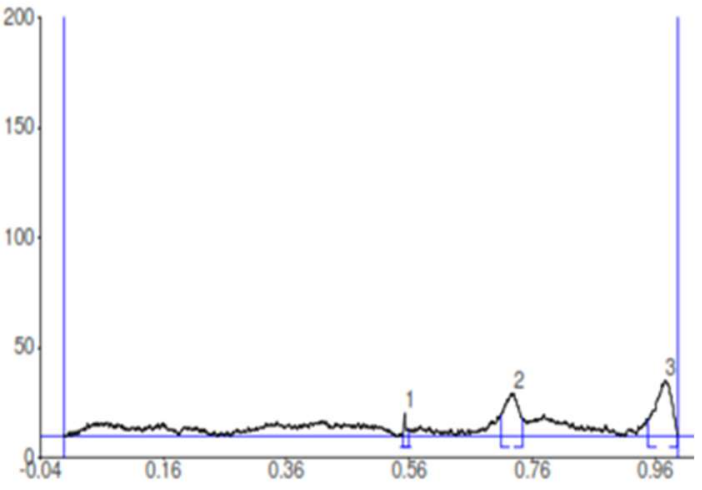

(b)

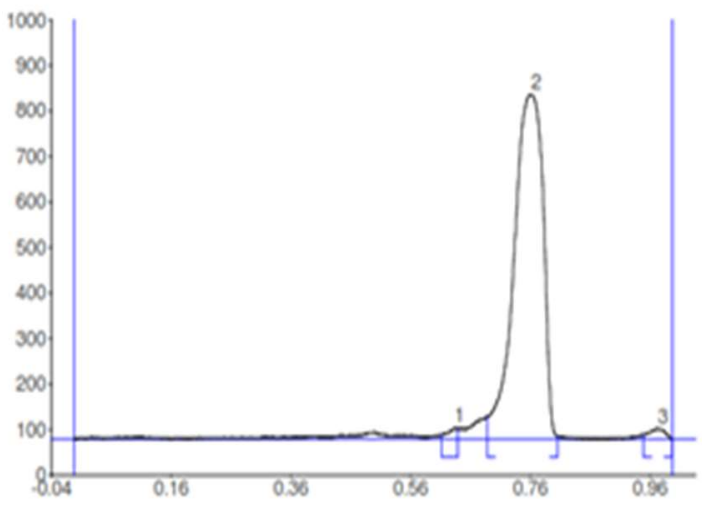

(d) 
RASĀYAN J. Chem.

Vol. 14 | No. 3 |2085-2089| July - September | 2021

Fig.-1: Representative HPTLC Chromatograms of (a) C. mangga 99\% Ethanol Extract (b) C. mangga 83\% Ethanol Extract (c) C. mangga $73 \%$ Ethanol Extract

Table-1: Curcumin Content in C. mangga Extracts obtained from HPTLC Measurement

\begin{tabular}{c|c|c|c}
\hline Samples & Rf & Area & Concentration $(\mu \mathrm{g} / \mathrm{mL})$ \\
\hline C. mangga $99 \%$ ethanol extract & 0.68 & 30296.2 & 9.94 \\
\hline C. mangga $83 \%$ ethanol extract & 0.71 & 851.7 & 1.78 \\
\hline C. mangga $73 \%$ ethanol extract & 0.68 & 15296.8 & 5.78 \\
\hline
\end{tabular}

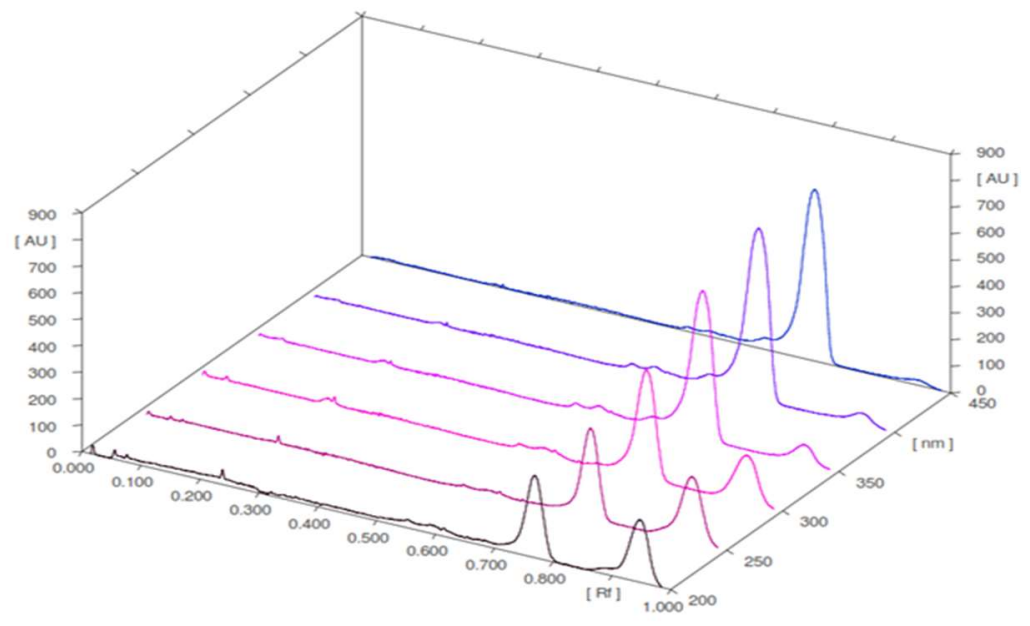

Fig.-2: Calibration Curve of Curcumin at Rf 0.69, detected at wavelength $425 \mathrm{~nm}$

\section{Delayed-Type Hypersensitivity (DTH) Response}

Various extracts of $C$. mangga were tested for their effects on delayed-type hypersensitivity response using the paw edema method as described previously ${ }^{15}$. All the samples were able to stimulate the cellular immune response as shown in Table-2. Amongst the sample extracts, C. mangga 99\% ethanol extract demonstrated the highest stimulation in DTH response (Table-2). However, the difference of ethanol/water solvent did not affect the DTH response significantly $(\mathrm{P}>0.05)$. In addition, the immunostimulatory activity of $C$. mangga $99 \%$ ethanol extract was higher than those of levamisole, as a positive control. DTH response is facilitated by the interaction of $\mathrm{T}$ lymphocytes-antigen that causes activation and cytokines release. This type of immune response requires sensitized T cells that respond 24-48 h after exposure to antigens. Thus, in this study, the paw volume was measured $24 \mathrm{~h}$ after $S$. aureus injection. T cell activation is followed by proliferation and differentiation. The Th-1, Th-2, Th-17, and CD4 T regulatory (Treg) cells are four subpopulations of CD4 T cells that perform different tasks. ${ }^{16}$ Th-1 induces inflammation by stimulating macrophages by producing IFN. ${ }^{17}$ The result was in accordance with a prior study that found C. mangga ethanol extract to be effective in boosting phagocytosis activity. ${ }^{8}$ The highest amount of curcumin was found in the $99 \%$ ethanol extract of $C$. mangga, according to HPTLC analysis. The results indicate that curcumin appears to play a significant role in the immunostimulatory activity of $C$. mangga rhizomes. Curcumin's immunostimulatory effect on dendritic cells (DSc) was also discovered in a prior study. ${ }^{18-19}$

Table-2: The Effect of $C$. mangga Extract on delayed-type hypersensitivity (DTH) Response (mean \pm SD)

\begin{tabular}{c|c}
\hline Samples & Paw Volume $(\Delta \mathrm{V})$ \\
\hline CMC Na $0.5 \%$ & $0.41 \pm 0.13$ \\
\hline Levamisol $25 \mathrm{mg} / \mathrm{kg} \mathrm{bw}$ & $1.63 \pm 0.09^{*}$ \\
\hline C. mangga extract $99 \% 400 \mathrm{mg} / \mathrm{kg} \mathrm{bw}$ & $2.18 \pm 0.20^{*}$ \\
\hline C. mangga extract $83 \% 400 \mathrm{mg} / \mathrm{kg} \mathrm{bw}$ & $1.61 \pm 0.27^{*}$ \\
\hline C. mangga extract $73 \% 400 \mathrm{mg} / \mathrm{kg} \mathrm{bw}$ & $1.71 \pm 0.43^{*}$ \\
\hline
\end{tabular}

$* \mathrm{P}<0.05$ significant to respective control

\section{CONCLUSION}

The highest amount of curcumin was found in the $99 \%$ ethanol extract of $C$. mangga rhizomes according to HPTLC quantitative analysis. Furthermore, the C. mangga 99\% ethanol extract demonstrated the highest 
RASĀYAN J. Chem.

Vol. 14 | No. 3 |2085-2089| July - September | 2021

stimulation on DTH response, although it was not different significantly as compared to other extracts. $99 \%$ ethanol extract of C. mangga revealed higher stimulation on cellular immunity as compared to positive control. Thus, further studies are required to elaborate on the mechanism of components in C. mangga to modulate the immune response.

\section{ACKNOWLEDGEMENT}

This study was supported by Universitas Sumatera Utara, Indonesia through scheme grant TALENTA year 2020 (Grant number of 4394/UN5.1.R/PPM/2020).

\section{REFERENCES}

1. E.L. Cooper, M.J. Ma, Journal of Traditional and Complementary Medicine, 7, 386(2017), https://doi.org/10.1016/j.jtcme.2016.12.002

2. S. Debnath, R. Chakravorty, and D. Devi, Asian Journal of Pharmacy and Technology, 10(4), 273(2020), https://doi.org/10.5958/2231-5713.2020.00045.8

3. A.B. Martinez, R Mattila, R.G. Font, J.H. Meurman, Medicina Oral, Patologia Oral, Cirugia Bucal, 19, e24(2014), https://doi.org/10.4317/medoral.19087

4. G. P. Khumalo, B. E. Van Wyk, Y. Feng, and I. E. Cock, Journal of Ethnopharmacology, 114436 (2021), https://doi.org/10.1016/j.jep.2021.114436

5. A.G. Atanasov, B. Waltenberger, E.P. Wenzig, T. Linder, C. Wawrosch, P. Uhrin, V. Temm, L. Wang, S. Schwaiger, E.H. Heiss, J.M. Rollinger, D. Schuster, J.M. Breuss, V. Bochkov, M.D. Mihovilovic, B. Kopp, R. Bauer, V. M. Dirsch, H. Stuppne, Biotechnology Advances, 33, 1582(2015), https://doi.org/10.1016/j.biotechadv.2015.08.001

6. M. Wink, Medicines (Basel), 2, 251(2015), https://doi.org/10.3390/medicines2030251

7. P. Sharma, P. Kumar, R. Sharma, G. Gupta, and A. Chaudhary, National Journal of Physiology, Pharmacy and Pharmacology, 7(6), 1(2017), https://doi.org/10.5455/njppp.2017.7.0203808032017

8. Yuandani, S. Yuliasmi, D. Satria, Rasayan Journal of Chemistry, 11(2), 844(2018), https://doi.org/10.31788/rjc.2018.1122097

9. C.V. Chandrasekaran, K. Sundarajan, J.R. Edwin, G.M. Gururaja, D. Mundkinajeddu, A. Agarwal. Pharmacognosy Research, 5, 71(2013), https://doi.org/10.4103/0974-8490.110527

10. W. Setyati, S. Subagiyo, R. Pramesti, and D. Pringgenies, Science and Technology Indonesia, 4(4), 94 (2019), https://doi.org/10.26554/sti.2019.4.4.94-100

11. C.S. Wahono, C. D. Setyorini, H. Kalim, N. Nurdiana, K. Handono. International Journal of Rheumatology, Article ID 7687053, 2017, https://doi.org/10.1155/2017/7687053

12. Yuandani, S. Yuliasmi, D. Satria, R.F. Dongoran, M.S. Sinaga, N.H,A. Marpaung, Rasayan Journal of Chemistry, 12(1), 1(2019), https://doi.org/10.31788/rjc.2019.1215050

13. A. Amalraj, A. Pius, S. Gopi, S. Gopi. Journal of Traditional and Complementary Medicine, 7, 205(2017), https://doi.org/10.1016/j.jtcme.2016.05.005

14. K. Ashraf, M. Mujeeb, A. Ahmad, M. Amir, M.N. Mallick, D. Sharma, Asian Pacific Journal of Tropical Biomedicine, 584(2012), https://doi.org/10.1016/s2221-1691(12)60278-0

15. L. Ahirwal, S. Singh, M.K. Dubey, V. Bharti, A. Mehta, S. Shukla, Archives of Biological Science Belgrade., 67, 561(2015), https://doi.org/10.2298/abs141027018a

16. M. Ruterbusch, K. B. Pruner, L. Shehata, and M. Pepper, Annual Review of Immunology, 38(1),705(2020), https://doi.org/10.1146/annurev-immunol-103019-085803

17. L.B. Ivashkiv, Nature Reviews Immunology, 18, 545(2018), https://doi.org/10.1038/s41577-018-0029$\underline{Z}$

18. M. Catanzaro, E. Corsini, M. Rosini, M. Racchi, C. Lanni, Molecules, 23, 2778(2018), https://doi.org/10.3390/molecules23112778

19. K. Rahimi, K. Hassanzadeh, H. Khanbabaei, S. M. Haftcheshmeh, A. Ahmadi, E. Izadpanah, A. Mohammadi, and A. Sahebkar, Current Medicinal Chemistry, 28, 1549(2021), https://doi.org/10.2174/0929867327666200515101228

[RJC-6247/2020] 